symptoms of these strains on sixteen host species, and indicates suitable tests for the presence of strains in a particular disease. The thermal death-point of spotted wilt complexes is considered to be about $10^{\circ} \mathrm{C}$. higher than the usual value of $42^{\circ} \mathrm{C}$. This is a rather unwelcome discovery from the point of view of possible control. On the other hand, the finding of a high degree of resistance to spotted wilt by Lycopersicum peruvianum is likely to be of considerable importance in breeding.

\section{Clutch and Brood-size in the Robin}

THe inquiry into clutch and brood-size in the robin (Erithacus rubecula), which was first reported by David Lack in 1946, has now been closed. Later observations show that the breeding season in Holland is later than in Britain but is earlier in North France, Germany and Switzerland than inland in Europe at a similar latitude (British Birds, 41, No. 4 ; April, 1948). The tendency for the average clutch-size of the robin in England and Wales to be highest in May, lower in April, and lower still in March, June and July has been confirmed It has also been shown that the average clutch-size is different in different years and there may be a correlation between fine weather and higher clutch. size. The average clutch-size in Ireland is approximately the same as in England and Wales, but in Scotland the average clutch-size is higher than in England and Wales. Nesting is more successful in May than in April, possibly because in April the ground vegetation is not so well grown as in May, Jeaving the nests less exposed to predators.

\section{International Committee for Bird Preservation}

THE report of the British Section of the International Committee for Bird Preservation (The Secretary, c/o British Museum (Natural History), Cromwell Road, London, S.W.7) is a record of much good work. For some years past naturalists and others have been perturbed by the decline in the wildfowl population of the world, and, among other things, the report contains an account of the Committee's work in investigating the situation as it affects the wildfowl of Europe. Among the activities are the ringing of duck to trace their migration routes. A duck decoy at Orielton is being used for this purpose, and ringing on a lesser scale is being carried out at other decoys in Great Britain. In 1947, the headquarters of the Committee, previously in Brussels, were transferred to London, and the British Museum (Natural History) is now the centre of the organisation, which has thirty-four national sections from all five continents.

\section{The Film in Scientific Research}

The Sciences Committee of the Scientific Film Association is arranging a one-day conference on "The Film in Scientific Research", to be held on October 12 at the Royal Institution, London. The chair will be taken by Mr. J. E. Cummins, chief scientific liaison officer in London of the Australian Government, and the Conference will be opened by Sir Robert Watson-Watt. The Conference will include discussions by British and foreign men of science on the value of scientific films as a research tool in various branches of science; the function of the research film in giving up-to-date information in a particular field; scientific films as an aid to the training of scientific workers; scientific films as a medium for explaining to the general public important results of scientific research; and technical aspects of the use of films in scientific research. The Conference will conclude with a two-hour showing of British and foreign research films. Material suggested for discussion and information as to the existence or availability of research films suitable for showing at the Conference should be sent to the Honorary Secretary, Sciences Committee, Scientific Film Association, 34 Soho Square, London, W.1, as soon as possible.

\section{Announcements}

WE regret to announce the following deaths:

Mr. S. G. Brown, F.R.S., known for his work on the gyroscopic compass and numerous other mechanical instruments, on August 7, aged seventy-five.

Mr. Harry E. Burton, principal astronomer and head of the Equatorial Division of the U.S. Naval Observa. tory from 1929 until June 30, 1948, on July 19, aged seventy.

Mr. J. R. Cowie, chairman of Council of the British Electrical and Allied Industries Research Association. on August 5.

Dr. Henry Guppy, C.B.E., librarian of the John Rylands Library, Manchester, on August 4, aged eighty-six.

THE chairman of the Royal Society's Library Committee, Prof. E. N. da C. Andrade, has accepted an invitation by the Council to become honorary librarian to the Society during his tenure of chairman. ship of the Library Committee.

Sir Lewis Fermor, director of the Geological Survey of India during 1932-35, has been elected Correspondant Etranger of the Société Géologique de France.

Sir Frank Stockdale, chairman of the Colonial Development Corporation, has been appointed chair. man of the governing body of the Imperial College of Tropical Agriculture, in succession to Sir Eric Macfadyen, who has been associated with the College since 1928.

Mr. Seton Lloyd, technical adviser to the Directorate of Antiquities in the Government of Iraq, has been appointed director of the British Institute of Archæology at Ankara in succession to Prof. J. Garstang, as from March 1, 1949.

Mr. R. McChlery, former Rhodes scholar and, since 1926, a member of the Agricultural Department, Salisbury, has been seconded to the Central African Council to take up the new appointment of Central African Scientific Liaison Officer in the United Kingdom, and to establish a Central African Scientific Liaison Office in the British Commonwealth of Nations Scientific Offices, London.

DR. A. E. A. Werner has recently joined the staff of the National Gallery, Trafalgar Square, as research chemist. He was previously reader in chemistry in Trinity College, Dublin.

A Conference of German Hygienists and Microbiologists is being held at Stuttgart during August 2527. Among the topics to be discussed are: tuberculosis in animals and its chemotherapy ; immunization against virus diseases ; milk hygiene in Germany ; human helminthiasis and its chemotherapy; human and animal trichinosis; rickettsia toxins; mor. phology and ecology of bacteria; bacteriology of enteritis; serum reactions, etc. Particulars can be obtained from Prof. G. Lutz, Heusteigstr. 66, Stuttgart-S. 